\title{
ОСОБЛИВОСТІ НАКАЗНОГО ТА ОКРЕМОГО ПРОВАДЖЕНЬ ЗА НОВИМ ЦИВІЛЬНО- ПРОЦЕСУАЛЬНИМ ЗАКОНОДАВСТВОМ УКРАЇНИ
}

\author{
ПОЛІЩУК Марина Геннадіївна - кандидат юридичних наук, доцент кафедри \\ цивільно-правових дисциплін юридичного факультету Дніпропетровського \\ державного університету внутрішніх справ
}

DOI:10.32782/LAW.2020.1.9

УДК $347+347.9$

Стаття присвячена проблемним аспектам окремого, наказного провадження та заочного розгляду справи в межах иивільного прочесуального законодавства Украӥни. В статті надається стисла характеристика кожного з проваджень, вказано на умови, при яких справи розглядаються в кожному 3 видів проваджень, а саме окремому, наказному, та заочному. Кожне із виділених видів провадження має притаманні лише даному виду особливості їх розгляду в суді. Тому характеристика провадження в иивільному судочинстві тягне за собою особливий порядок (процедуру) розгляду окремих категорій юридичних справ; врегульовані нормами иивільного процесуального права порядок провадження у ицвільних справах, яке визначається системою взаємопов язаних ициільних процесуальних прав та обов язків $і$ ијивільних процесуальних дій, якими вони реалізуються субгектами - судом і учасниками процесу; визначає характер і специфікою матеріального права або охоронюваного законом інтересу, які підлягають захисту; процесуальний порядок порушення, розгляду, вирішення певноі групи иивільних справ. 315 грудня 2017 року набрали чинності зміни до Цивільно-прочесуального кодексу, а по суті ицвільний процесуальний закон викладено в новій редакцій, при извому його суттєво $і$ докорінно змінено. 3 иього часу суди застосовують нові прочесуальні норми. Отже, $є$ підстава попереднъо проаналізувати наступні види проваджень. Відповідно до Цивільно-прочесуального кодексу завданнями иивільної о судочинства є охо- рона прав та законних інтересів бізичних, юридичних осіб, держави шляхом всебічного справедливого, неупередженого та своєчасного розгляду і вирішення ицвільних ицвільних справ у повній відповідноси $i$ чинним законодавством. Законодавство про иивільне судочинство встановлюс порядок розгляду иивільних справ, об>єднаних за матеріальними ознаками в три види проваджень позовне; окреме; наказне.

Ключові слова: окреме провадження, наказне провадження, заочний розгляду справи.

\section{Вступ}

Верховною Радою України 18 березня 2004 р. було прийнято Цивільний процесуальний кодекс України (ЦПК). Але, 23 листопада 2017 року Президентом України підписано Закон про внесення змін до Господарського процесуального кодексу України, Цивільного процесуального кодексу України, Кодексу адміністративного судочинства України та інших законодавчих актів. Цей нормативно-правовий акт покликаний внести істотні новації до діючого цивільного процесуального законодавства України, зробити процес захисту прав та законних інтересів у рамках цивільної юрисдикції максимально швидким, ефективним та прозорим. Так, було введено провадження, які сприяють розумному спрощенню процедури, зокрема: наказне провадження, що закріплене розділом II, ст. 160-173; заочний розгляд справи, що закріплено розділом III, главою 8, ст. 280- 
292; окреме провадження, що закріплено розділом IV, ст. 293-350.

\section{Постановка проблеми}

На сьогодні в Україні реалізація інституту заочного, окремого та наказного провадження в цивільному процесуальному законодавстві не позбавлено недоліків, що іноді призводить до суттєвого порушення прав і законних інтересів осіб. Із моменту виникнення наведених інститутів у ЦПК вони зазнали істотної трансформації, відповідно, потребують серйозного доопрацювання. Цим й обумовлено вибір теми дослідження та її актуальність.

\section{Аналіз останніх досліджень}

Над розкриттям питання проблем аспектів окремого, наказного провадження та заочного розгляду справ у межах цивільного процесуального законодавства працювало багато юристів, учених у галузі цивільного процесуального законодавства, зокрема: К. Анненков, М. Балюка, С. Бичкова, Л. Буркацький, А. Ванеєва, Р. Гаврік, Ф. Горбонос, П. Єлісейкін, М. Зайцева, В. Комаров, В. Кравчук, Т. Кучер, О. Онішко, Т. Сахнов, С. Сеннік, I. Татулич, В. Тертишнікова, М. Трипольська, О. Угриновська, С. Фурса, Г. Чурпіта, М. Штефан, М. Ясинюк. Незважаючи на широкий спектр дослідження аспектів видів цивільних процесуальних проваджень, у теорії цивільного процесуального права є багато спірних питань, що стосуються проваджень (окремого, наказного та заочного), зокрема процесуальних особливостей розгляду та вирішення справ, які ще недостатньо вивчені й потребують поглибленого дослідження та аналізу.

Мета статті - визначити основні проблемні аспекти окремого, наказного провадження та заочного розгляду справ у межах прийняття чинного цивільного процесуального законодавства України.

\section{Виклад основного матеріалу}

Необхідно зазначити, що реалізація окремого, наказного та заочного провадження в цивільному процесуальному законодавстві України не позбавлена недоліків, що іноді призводить до суттєвого порушення прав і законних інтересів осіб, а також проблемних аспектів, які виникають внаслідок неузгодженості законодавства.

Відповідно до ч. 3 ст. 19 ЦПК України, встановлено перелік видів провадження, за якими розглядають цивільні справи, до яких входить наказне, яке характеризуються особливою формою судового рішення [1].

Як зазначає Т. М. Кучер, судовий наказ має сприяти зростанню оперативності судового захисту суб'єктивних прав і ефективності виконання, зменшенню навантаження на суди із розгляду, підвищенню в громадян почуття відповідальності за прийняття ними зобов'язання, посиленню превентивної функції права, зміцненню законності та правопорядку, формуванню поважного ставлення до права та судової влади [7, с. 137].

Згідно із ст. 160 ЦПК України, судовий наказ $є$ особливою формою судового рішення, який видається судом тільки за результатами розгляду вимог, передбачених ЦПК України.

У новій редакції законом збільшений перелік вимог, за якими може бути видано судовий наказ, що закріплено в ст. 161 ЦПК України, зокрема:

1. Судовий наказ може бути видано, якщо:

1) заявлено вимогу про стягнення нарахованої, але не виплаченої працівникові суми заробітної плати та середнього заробітку за час затримки розрахунку;

2) заявлено вимогу про компенсацію витрат на проведення розшуку відповідача, боржника, дитини або транспортних засобів боржника;

3) заявлено вимогу про стягнення заборгованості за оплату житлово-комунальних послуг, телекомунікаційних послуг, послуг телебачення та радіомовлення з урахуванням індексу інфляції та 3 відсотків річних, нарахованих заявником на суму заборгованості;

4) заявлено вимогу про стягнення аліментів у розмірі на одну дитину - однієї чверті, на двох дітей - однієї третини, на трьох і більше дітей - половини заробітку (доходу) платника аліментів, але не більше 


\section{Адміністративне право}

десяти прожиткових мінімумів на дитину відповідного віку на кожну дитину, якщо ця вимога не пов'язана із встановленням чи оспорюванням батьківства (материнства) та необхідністю залучення інших заінтересованих осіб;

5) заявлено вимогу про стягнення аліментів на дитину у твердій грошовій сумі в розмірі 50 відсотків прожиткового мінімуму для дитини відповідного віку, якщо ця вимога не пов'язана із встановленням чи оспорюванням батьківства (материнства) та необхідністю залучення інших заінтересованих осіб;

6) заявлено вимогу про повернення вартості товару неналежної якості, якщо є рішення суду, яке набрало законної сили, про встановлення факту продажу товару неналежної якості, ухвалене на користь невизначеного кола споживачів;

7) заявлено вимогу до юридичної особи або фізичної особи - підприємця про стягнення заборгованості за договором (іншим, ніж про надання житлово-комунальних послуг, телекомунікаційних послуг, послуг телебачення та радіомовлення), укладеним у письмовій (в тому числі електронній) формі, якщо сума вимоги не перевищує ста розмірів прожиткового мінімуму для працездатних осіб.

Особа має право звернутися до суду з вимогами, визначеними у частині першій цієї статті, в наказному або в спрощеному позовному провадженні на свій вибір. [1].

Частина 1 ст. 293 ЦПК України закріплює, що окреме провадження - це вид непозовного цивільного судочинства, у порядку якого розглядаються цивільні справи про підтвердження наявності або відсутності юридичних фактів, що мають значення для охорони прав та інтересів особи або створення умов здійснення нею особистих немайнових чи майнових прав або підтвердження наявності чи відсутності неоспорюваних прав [1].

У частині 2 ст. 293 ЦПК України перелічено одинадцять категорій цивільних справ окремого провадження, особливості порядку розгляду й вирішення яких закріплено в ст. 293 розд. IV ЦПК України, зокрема:

1) обмеження цивільної дієздатності фізичної особи, визнання фізичної особи неді- єздатною та поновлення цивільної дієздатності фізичної особи;

2) надання неповнолітній особі повної цивільної дієздатності;

3) визнання фізичної особи безвісно відсутньою чи оголошення ії померлою;

4) усиновлення;

5) встановлення фактів, що мають юридичне значення;

6) відновлення прав на втрачені цінні папери на пред'явника та векселі;

7) передачу безхазяйної нерухомої речі у комунальну власність;

8) визнання спадщини відумерлою;

9) надання особі психіатричної допомоги в примусовому порядку;

10) примусову госпіталізацію до протитуберкульозного закладу;

11) розкриття банком інформації, яка містить банківську таємницю, щодо юридичних та фізичних осіб [1].

Як зазначає Г. В. Чурпіта, відповідно до ч. 3 ст. 234 ЦПК України, в порядку окремого провадження розглядають також: справи про надання права на шлюб; справи про розірвання шлюбу за заявою подружжя, яке має дітей; справи про розірвання шлюбу за заявою будь-кого з подружжя, якщо один 3 нього засуджений до позбавлення волі; справи про встановлення режиму окремого проживання за заявою подружжя; інші справи у випадках, встановлених законом. Крім того, відповідно ЦПК України, у якій визначено конкретні справи про встановлення фактів, що мають юридичне значення, у судовому порядку можуть бути встановлені також інші факти, від яких залежить виникнення, зміна або припинення особистих чи майнових прав фізичних осіб, якщо законом не визначено іншого порядку їх встановлення [11, с. 46-47].

Інститут заочного рішення спрямований, 3 одного боку, на розширення засад диспозитивності в цивільному процесі (зокрема, свободи розсуду сторін), та, з іншого боку, на запобігання можливості зловживання процесуальними правами та встановленням відповідальності за ці зловживання [5].

Як зазначають Ф. В. Горбонос та Н. $\lambda$. Іващук, то гл. 8 розділу III ЦПК України регламентовано інститут заочного рішення, 
яке визначається як рішення, що ухвалюється судом у разі неявки в судове засідання відповідача, який належним чином повідомлений і від якого не надійшло повідомлення про причини неявки або зазначені ним причини визнані неповажними та якщо позивач не заперечує проти такого вирішення справи [5].

Відповідно до ст. 280 ЦПК України, в разі неявки в судове засідання відповідача або всіх відповідачів, які належним чином повідомлені та від яких не надійшло заяви про розгляд справи за їх відсутності або якщо повідомлені ним причини неявки визнані неповажними, суд може ухвалити заочне рішення на підставі наявних у справі доказів, якщо позивач не заперечує проти такого вирішення справи [1].

Інститут заочного розгляду не порушує конституційного принципу змагальності процесу, оскільки забезпечується повною інформованістю сторін про позицію кожного, судове засідання провадиться за загальними правилами, у відповідача зберігається право на оскарження постановленого заочного рішення [3, с. 487].

Аналіз положень ЦПК щодо окремого, наказного провадження та заочного розгляду справи дає змогу дійти висновку, що зазначений інститут потребує серйозного доопрацювання, а практика перегляду та виконання заочних рішень свідчить про існування системних проблем.

Хоча процедура вирішення цивільних справ у порядку наказного провадження загалом належним чином врегульована в розділі II ЦПК України й має багато позитивних моментів, однак у практиці застосування наказного провадження виникають деякі проблеми, зокрема:

1) у наказному провадженні до учасників процесу належать не позивач і відповідач, а стягувач (кредитор) та боржник. Утім у деяких статтях ЦПК законодавець використовує щодо стягувача термін “заявник” (як у п. 2 ч. 2 ст. 160 ЦПК), а стосовно боржника - “заінтересована особа" (ЦПК), буквальне тлумачення та співставлення відповідних термінів як у Цивільному коддексі, так і в Цивільно процесуальному кодексі, робить цілком очевидним висновок про неможли- вість застосування позовної давності в наказному провадженні [1].

Відповідно до Пленуму Верховного Суду України “Практика розгляду судами цивільних справ в порядку наказного провадження”, існують дві позиції щодо застосування позовної давності в наказному провадженні:

а) позовна давність свідчить про наявність спору про право і виключає прийняття заяви про видачу судового наказу;

б) позовна давність не повинна враховуватись судом без заяви зацікавленої особи, а наявні в інституті наказного провадження процесуальні засоби не виключають можливості звернення із заявою про застосування позовної давності під час подачі заяви про скасування судового наказу [2];

2) на сьогодні склалася ситуація, коли працівник не має можливості витребувати документи, необхідні йому для розгляду його заяви про видачу судового наказу про стягнення нарахованої, але невиплаченої заробітної плати шляхом подання відповідного клопотання до суду, заяви до прокуратури про витребування зазначених документів у порядку прокурорського нагляду або Уповноваженого Верховної Ради України $з$ прав людини про здійснення захисту у випадках, коли працівник не має можливості самостійно захищати свої права [4, с. 92], зазначене викликане відсутністю можливості подання в наказному провадженні клопотання про витребування необхідних документів у роботодавця;

3) частими є факти, що боржник не інформується про подання заяви про видачу судового наказу, і відповідач про розгляд справи за його відсутності, як правило, дізнається вже за фактом. Тому процесуальне законодавство строк набрання чинності судовим наказом прив'язує до дати отримання копії судового наказу боржником (відповідачем) [8, с. 220];

4) під час вирішення справ про стягнення нарахованої, але невиплаченої заробітної плати, буває, що працівник майже завжди, крім вимог про стягнення нарахованої, але не виплаченої заробітної плати, одночасно заявляє вимоги про стягнення середнього заробітку за час затримки розрахунку, про компенсацію втрати частини доходів у 


\section{Адміністративне право}

зв'язку 3 порушенням установлених строків їх виплати і відшкодування моральної шкоди. У таких випадках суд задовольняє такі заяви лише в частині стягнення нарахованої, але не виплаченої заробітної плати, а щодо інших вимог, як таких, що повинні бути вирішені в позовному провадженні, відмовляє. Однак, як свідчить судова практика, судовий наказ може бути видано не лише на суму заборгованості із заробітної плати, а й на суму компенсації за порушення строків її виплати, оскільки вона входить до структури заробітної плати [4, с. 92];

5) та інші.

Що стосується окремого провадження, це провадження є самостійним видом цивільного судочинства й відрізняється від інших проваджень своєю правовою природою та особливостями процесуального порядку розгляду справ, незважаючи на низку позитивних моментів, які викликані окремим провадженням, 6 низка недоліків, які виникають через неузгодженість законодавства, зокрема:

1) відсутність спору про право тягне за собою відсутність сторін з протилежними інтересами (позивача й відповідача), а також третіх осіб;

2) усіх інших осіб, які братимуть участь у справі, закон наділяе статусом зацікавлених осіб. Однак на практиці існують випадки, коли зацікавлених осіб узагалі не встановлюють і не викликають до суду, а невстановлення заінтересованих осіб призводить до неможливості їх вступу в процес для захисту своїх інтересів, а внаслідок цього не будуть всебічно з'ясовані всі обставини справи. Саме тому П. П. Єлісєйкін стверджував про необхідність надання зацікавленій особі можливості на порушення спору й можливу погану юридичну обізнаність цих осіб [6, с. 67], що також може негативно вплинути на судовий процес;

3) на практиці зазначають також випадки, коли заявників називають позивачами, а зацікавлених осіб - відповідачами, свідками. Це пояснюється тим, що законодавець не дає визначення заявника і зацікавленої особи. Тому необхідно, щоб ці дефініції були внесені до норм ЦПК України;
4) відсутність правового спору, а відповідно і сторін в окремому провадженні унеможливлює пред'явлення зустрічного позову, заміну сторони, укладення мирової угоди, звернення до третейського суду тощо [9, c. 77];

5) принцип диспозитивності діє не в повному обсязі, оскільки в окремому провадженні не застосовують таких характерних для позовного провадження інститутів як мирова угода, визнання позову, відмова від позову, забезпечення позову;

6) порушено принцип одноособовості й колегіальності розгляду справ - усі справи окремого провадження розглядаються суддею одноособово, за винятком справ, перелічених в пунктах ЦПК, які розглядають у складі одного судді та двох народних засідателів;

7) у процесуальній науці протягом багатьох років дискутують 3 приводу того, чи можливий в окремому провадженні спір про факт. I чи завжди спір про факт тягне за собою спір про право;

8) та інші.

Розглядвючи функціонування інституту заочного провадження в судовому процесі України, слід зазначити, що провадження не позбавлено недоліків, що іноді призводить до суттєвого порушення прав та законних інтересів однієї або обох сторін.

Інститут заочного розгляду в ЦПК зазнав істотної трансформації 3 часу свого виникнення. Аналіз положень ЦПК щодо заочного розгляду справи дає змогу дійти висновку, що зазначений інститут потребує серйозного доопрацювання, а практика перегляду та виконання заочних рішень свідчить про існування системних проблем, зокрема:

1) неврегульованими $\epsilon$ правомочності суду щодо випадків незгоди позивача на заочний розгляд справи;

2) непоодинокі випадки, коли суд ухва^ює заочне рішення, незважаючи на явку в судове засідання представника відповідача 3 належно оформленими повноваженнями. Неявка представника відповідача може стати додатковою підставою для скасування заочного рішення; 
3) на практиці зустрічаються ухвалення заочних рішень у справах, де відповідач не був повідомлений належним чином про судові засідання, що призводить до суттєвого порушення інтересів відповідача;

4) відсутність єдиної практики набрання заочним рішенням законної сили через прогалини в ЦПК. Заочне рішення набирає законної сили відповідно до загального порядку, встановленого ЦПК;

5) порушення інтересів позивача через те, що не визначено на сьогодні, як діяти суду, якщо копію заочного рішення неможливо вручити відповідачу 3 тих чи інших причин (ухилення відповідача від його отримання, розгляд справи за останнім відомим місцем проживання відповідача, зміна місця проживання відповідача та недобросовісне виконання ним обов'язку повідомити суд про відповідні зміни тощо);

6) хибне визнання заочного рішення таким, що набрало законної сили після спливу десяти днів 3 дня його проголошення, i звернення його до примусового виконання;

7) наявність хибної практики зупинення стягнення за виконавчим документом, що за своєю сутністю є заходом забезпечення позову, аналогією закону, відповідно до якої до заяви про перегляд заочного рішення застосовують загальні норми ЦПК;

8) відсутність законодавчо визначених підстав визнання виконавчого листа таким, що не підлягає виконанню;

9) та інші [10, с. 54].

\section{Висновки}

Проаналізовано основні проблеми наказного, окремого провадження та заочного розгляду справи в межах цивільного процесуального законодавства України, які виникли 3 прийняттям чинного ЦПК України, відповідно до якого введені провадження, які сприяють розумному спрощенню процедури, зокрема: наказне провадження, що закріплене розділом II, ст. 160-173; заочний розгляд справи, що закріплено розділом III, главою 8, ст. 280-292; окреме провадження, що закріплено розділом IV, ст. 293-350

Наказне провадження $\varepsilon$ окремим самостійним видом цивільного судочинства України в суді першої інстанції. Крім того, йому притаманні свої особливості, норми, категорії, інститути. По-перше, для цього виду судочинства характерна своя форма судового рішення - судовий наказ, по-друге - своя процедура (підстави, строки, вимоги, порядок розгляду).

"Наказне провадження" потребує суттевих змін. Зокрема ЦПК України потребує доповнення положенням щодо права “подання письмових документів, що підтверджують правомірність його заперечень” разом із заявою про скасування судового наказу.

Окреме провадження є самостійним видом цивільного судочинства, який характеризується специфічним, процесуальним порядком розгляду й вирішенням чітко визначених процесуальним законом категорій цивільних справ, у яких суд установлює дії, події, стан, здійснює захист охоронюваних законом інтересів громадян і організацій.

Доцільним було б доповнити главу 8 ЦПК “Заочний розгляд справи” та Закон України "Про виконавче провадження" від 21.04.1999 р. № 606 нормами, які надавали 6 додаткові можливості суду щодо зупинення виконавчого провадження за аналогією, коли виконання рішення суду зупиняється до розгляду справи по суті судом касаційної інстанції.

\section{入ітература}

1. Цивільний процесуальний кодекс України: Закон від 18.03.2004 р. № 1618IV Відомості Верховної Ради України. 2018. Ciт. 419.

2. Про практику розгляду судами заяв цивільних справ в порядку наказного провадження: Пленум від 23.12.2011 р. Відомості Верховного Суду України. № 14. 2011.

3. Анненков К. Н. Опыт комментария к Уставу гражданского судопроизводства К. Н. Анненков. -Санкт-Петербург, 1884. T. 4. C. 784.

4. Гаврік Р. О. Окремі практичні проблеми, які вникають при застосуванні наказного провадження як форми захисту трудових прав працівників Р. О. Гаврік Науковий вісник ХДУ. 2015. № 3. С. 91-94.

5. Горбонос Ф. В. Поняття та умови заочного провадження справ в судах [Електро- 
нний ресурс] Ф. В. Горбонос, Н. А. Іващук Наукові записки Аьвівського університету бізнесу та права. 2012. Вип. 8. С. 147-151. -Режим доступу: http://nbuv.gov.ua/UJRN/ Nzlubp_2012_8_36.

6. Елисейкин П. Ф. Судебное установление фактов, имеющих юридическое значение П. Ф. Елисейкин. - Москва : Юрид. лит., 1973. $128 \mathrm{c}$.

7. Кучер Т. М. Шляхи приведення процедури наказного провадження у відповідність до принципів цивільного процесу та норм міжнародного права Т. М. Кучер Часопис Київського університету права. 2009. Вип. 3. С. 137-140.

8. Сеник С. Поняття та характерні ознаки наказового провадження С. Сеник Biсник Аьвівського університету. Серія юридична. Вип. 51. С. 218-222.

9. Татулич I. Ю. Процесуальні особливості розгляду та вирішення справ окремого провадження I. Ю. Татулич Науковий вісник Чернівецького університету. 2013. № 682. С. 76-80.

10. Трипольська М. Проблемні аспекти заочного провадження в цивільному судочинстві М. Трипольська Вісник НААУ. 2015. № 7-8 (15). С. 52-55.

11. Чурпіта Г. В. Деякі аспекти суб'єктного складу справ окремого провадження, що виникають із сімейних відносин Г. В. Чурпіта Юридична наука. 2011. № 6. C. $46-52$.

\section{Polishchuk M. \\ PROBLEM ASPECTS OF INDIVIDUAL, ORDINARY PROCEEDINGS AND IN- COUNGIL CONSIDERATION OF THE CASE IN TERMS OF GIVIL PROCEDURAL LEGISLATION OF UKRAINE}

The article is devoted the problem aspects of separate, order realization and extra-mural consideration of business within the limits of civil judicial legislation of Ukraine. In the article the compressed description is given each of realizations, it is indicated on terms at which taken shipping in each of types of realizations, namely to separate, order, and zaochnomu. Each of the selected types of realization has inherent only this type of feature of their consideration in a court.

Therefore description of realization in the civil rule-making pulls the special order (procedure) of consideration of separate categories of legal businesses; well-regulated the norms of civil judicial law order of realization in civil cases, that is determined by the system of взаємопов'язаних civil judicial laws and duties and civil judicial actions they will be realized that by subjects - court and participants of process; character determines and by the specific of material right or охоронюваного law of interest, that is subject to defence; judicial order of violation, consideration, decision of certain group of civil cases.

From December, 15, 2017 changes inured in a Civilly-judicial code, and essentially a civil judicial law is expounded in a new release, here him substantially and it is radically changed. From this time courts apply new judicial norms. Thus, there is founding preliminary to analyse the next types of realizations. In accordance with a Civilly-judicial code by the tasks of civil is guard of rights and legal interests physical, legal entities, states by allround just, timely consideration and dispatch of civil civil businesses in complete and by a current legislation. Legislation about the civil rule-making вс order of consideration of the civil cases incorporated after signs in three types of realizations lawsuit; separate; order.

Keywords: separate realization, order realization, extra-mural to the trial of business. 